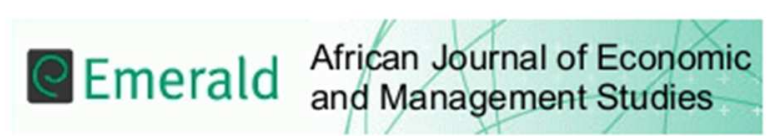

\title{
Macroeconomic determinants of interest rate spreads in Ghana
}

\begin{tabular}{|r|l|}
\hline Journal: & African Journal of Economic and Management Studies \\
\hline Manuscript ID & AJEMS-12-2015-0143.R1 \\
\hline Manuscript Type: & Research Paper \\
\hline Keywords: & $\begin{array}{l}\text { Interest rate spreads, lending interest rate, deposit interest rate, ARDL, } \\
\text { ECM }\end{array}$ \\
\hline \multicolumn{2}{|c}{} \\
\hline
\end{tabular}

SCHOLARONE ${ }^{\prime \prime}$

Manuscripts 


\subsection{Introduction}

In the last few decades Ghana has pursued reforms in its financial sector, aimed at making the sector more efficient and sustainable. The reforms programme which was implemented under the Financial Sector Adjustment Programme (FINSAP) and the Financial Sector Strategic Plan (FINSSP) involved the liberalisation of the financial sector, restructuring of financial institutions, and enhancement of banking regulations. This was done largely to support the economic growth agenda of the country. These reforms have resulted in various regulations and laws that have allowed more entry into the financial market, as well as greater openness aimed at reducing commercial bank collapse and folding up (Korsah et al., 2001; Aryeetey and Senbet, 2004; Biekpe, 2011). What is crucial among the reform policies is the adoption of a freely floating and highly independent interest rate system. Within this context, commercial banks are freely able to determine their interest rates after taking into consideration factors specific to the banking industry (including bank-specific costs and profit factors), and the monetary policy rate as determined by the central bank (see Korsah, et al., 2001; Aryeetey and Senbet, 2004; Biekpe, 2011). This has led to disparities on what is received on deposits compared with what is paid on loans, with the former mostly a lot lower than the latter. The huge spread (lending rate minus deposit rate) has been attributed to unfavorable macroeconomic factors and factors specific to the banking industry (Bawumia, et al., 2005; Aboagye et al., 2008; Owusu-Antwi, 2013; Quartey and Afful-Mensah, 2014). Interest rate spreads indicate the cost of bank intermediation. Therefore, high spreads may signal inefficiency in the banking industry which may negatively affect savings and investment in the domestic economy (see Brock and Rojas Suarez, 2000). Increasing interest rate spreads are more likely to be detrimental to developing countries given the fact that their financial markets are not well developed and their huge dependence on banks for financial needs (Peria and Mody, 2004).

A plot of deposit and lending rates in Ghana for the period 1980-2013 indicates lending rate was much higher for all periods than deposit rate. Notwithstanding, the early 1980s saw reduced spreads possibly due to the fact that the financial sector was not much liberalised as rates were largely controlled by the government. Since financial liberation in the mid-1980s, spreads have continually widened with the greatest differences occurring between 1994 and 2000. This is not surprising as the period 1994-2000 was characterized by huge macroeconomic instability as the economic gains from the Structural Adjustment Programme were largely eroded (ISSER, 2013). Periods since then have seen fluctuating trends between the two rates, with lending rate much higher than deposit rate. With the current macroeconomic fundamentals of the economy gradually nearing those of the 1994-2000 periods (see ISSER, 2013; Bawumia, 2014; IMF, 2014), questions are often asked as to whether similar implications on spreads should be expected. It is worth noting that comparatively, Ghana's financial sector is relatively becoming more developed, liberalised and less concentrated. This implies competition is now greater which may be reducing collusion among banks in the determination of interest rates. These do not however preclude any negative effects of macroeconomic variables on spreads in Ghana. 
Figure 1: Trends in Lending and Deposit Rate in Ghana for 1980-2013

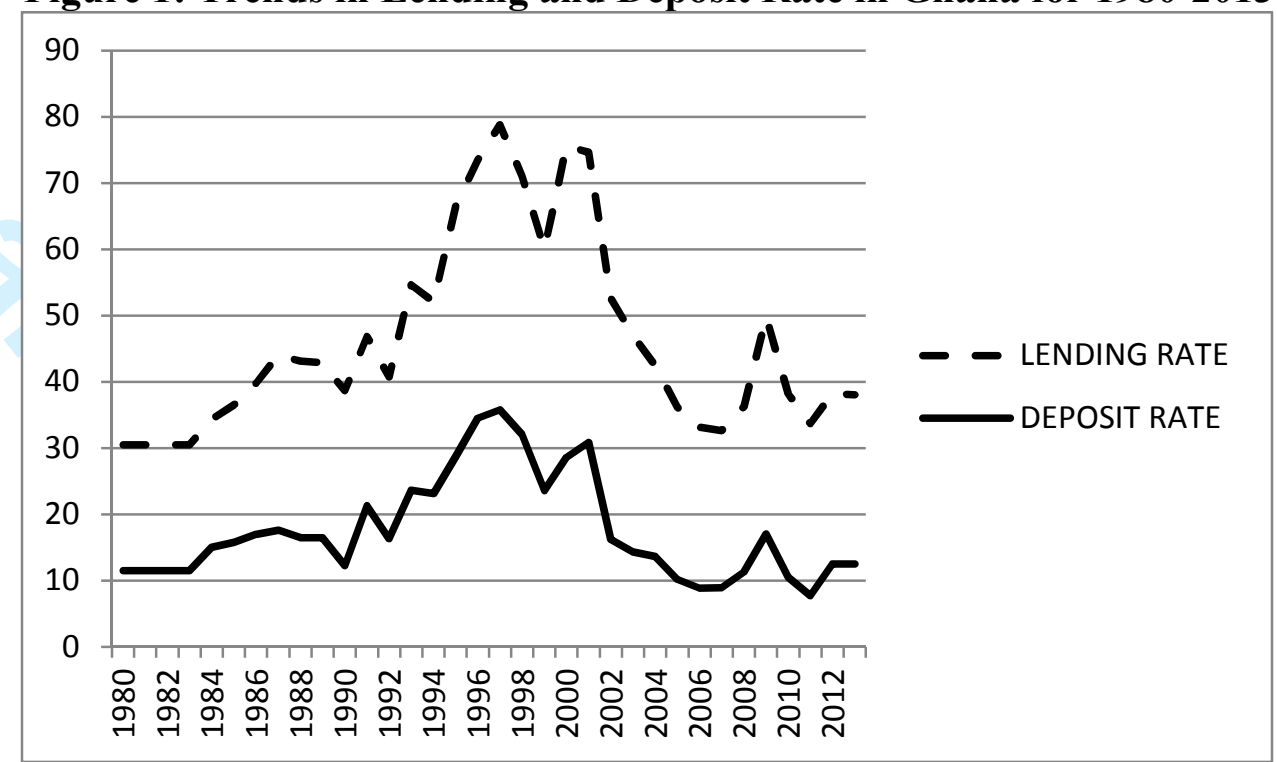

Source: Authors

Why are deposit interest rates significantly different from lending rates in Ghana? What causes the gap between the two rates, with the latter largely higher than the former? These two questions bother lenders and borrowers more often than has been considered. The situation is further worsened by the fact that monetary policy rate keeps rising, deficits are increasing, crowding-out effect keeps deepening, the Ghana Cedi is depreciating, inflation rates keep rising, and economic growth is declining in recent years (ISSER, 2013; Bawumia, 2014). Do these happenings have any implications for interest rate spreads in Ghana? The study therefore examines macroeconomic determinants of interest rate spreads in Ghana for the period 19802013.

It is worth stating that there may be a trade-off regarding the relevance or otherwise of spreads. As earlier indicated, a banking atmosphere with high spreads may suggest low banking competition, excessive risk taking or inefficiency. Notwithstanding, an atmosphere characterized by high spreads may lead to high bank profits, which can enhance the safety and reliability of the banking system if such funds form part of the system's capital base. Barajas et al. (1999) particularly notes this situation for developing countries. As to whether low spreads should be preferred to higher ones or vice versa is however unclear (see Barajas et al., 1999).

While some authors attribute the determinants of spreads to the structure of the capital market (see Bain, 1951; Hannan and Berger, 1991; Neumark and Sharpe, 1992; Barajas et al, 2000; Jayaraman and Sharma, 2003; Hofman and Mizen, 2004; Chirwa and Mlachila, 2004; Samuel and Valderrama, 2006; Kwakye, 2010; Sarpong et al., 2011), others "blame" bank-specific factors (see Ho and Saunders, 1981; Demirguc-Kunt and Huizinga, 1998; Ngugi, 2001; Moore and Craigwell, 2002; Brock and Rojas-Suarez, 2000; Robinson, 2000; Gelos, 2006; Sologoub, 2006; and Crowley, 2007; Garr and Kyereboah-Coleman, 2013). These arguments notwithstanding, spreads have also been found to be influenced by macroeconomic factors (see Randall, 1998; Brock and Franken, 2002, 2003; Tennant, 2006; Crowley, 2007; Folawewo, and Tennant, 2008; Sheriff and Amoako, 2014). Although similar studies on Ghana has been 
conducted (see Bawumia, et al., 2005; Aboagye et al., 2008; Kwakye, 2010; Garr and Coleman, 2013; Sarpong et al., 2013; Churchill et al., 2014; Sheriff and Amoako, 2014; AmuakwahMensah and Marbuah, 2015) the present paper differ from these ones for the following reasons. First, it introduces money growth and a measure of institutional quality in determining interest rate spread. These variables have not been considered in previous studies on Ghana. Broad money growth creates inflationary pressures. This increases risk that requires larger interest rate spreads to reduce bank losses. Good institutional quality is expected to among others provide adequate monitoring, regulation and evaluation to ensure the financial industry is efficient and effective. Secondly, it makes use of exchange rate volatility, deposit interest rate volatility, and lending interest rate volatility. These variables measure macroeconomic instability and are important as macroeconomic instability increases risks and uncertainties faced by the financial sector, requiring increases in interest rate spreads to reduce possible bank losses.

The rest of the paper is structured as follows: The next section discusses the model and methodology adopted for the study. Section three analyzes the estimation results obtained while the final section shows the implications of the study and offers the concluding remarks.

\subsection{Methodology}

\subsection{Model specification and data}

To examine macroeconomic determinants of interest rate spreads in Ghana, the paper adopts the equation specified below:

$\operatorname{lnIRS_{t}}=\beta_{0}+\beta_{1} \operatorname{lnINF}_{t}+\beta_{2} E E R_{-} v o l_{t}+\beta_{3} D R_{-} v o l_{t}+\beta_{4} M 2_{-} g_{t}+\beta_{5} \ln M P_{t}+\beta_{6} P T_{t}+$ $\beta_{7} D E F_{t}+\beta_{8} \ln Y_{t}+\beta_{9} \ln C R O W D_{t}+\beta_{10} L R_{-} v_{0} l_{t}+\varepsilon_{t}$

where $I R S, I N F, E E R_{v o l}, D R_{v o l}$, and $M 2_{g}$ represent interest rate spread, inflation, exchange rate volatility, deposit interest rate volatility, and broad money growth respectively. $M P, P T$, $D E F, Y, \varepsilon$ indicate monetary policy rate (i.e. the prime rate), institutional quality (proxied by Polity2), fiscal deficits, real GDP per capita, and the error term respectively. CROWD and $L R_{\text {vol }}$ refer to public sector borrowing from commercial banks (crowding-out) and lending interest rate volatility respectively. $\ln$ is the natural $\log$ operator while $t$ shows the time-variant nature of the data used. Fiscal deficit is defined as overall balance including grants and net lending but excluding divestiture receipts and liabilities expressed as a percentage of GDP. The dependent variable (interest rate spread) is calculated as Lending interest rate minus Deposit interest rate. Exchange rate, lending interest rate, and deposit interest rate volatilities are calculated using the GARCH $(1,1)$ approach. CROWD is measured as Domestic credit provided by the financial sector minus Domestic credit to private sector by banks. CROWD is introduced to measure the extent of public sector involvement in the banking sector or "crowding-out" effect of government intervention in the banking sector. Inflation is measured as consumer price index. $\beta_{1}$ is expected to be positive and statistically significant since it reflects the cost of doing business in the banking sector. Specifically, higher inflation is expected to cause higher inflation-adjusted interest rate spreads if it makes banks charge risk premiums. $\beta_{2}$ is also expected to be positive and statistically significant since increasing macroeconomic instability raises the risks faced by banks. $\beta_{3}$, and $\beta_{9}$, may be positive or negative. This is explained by the fact that, given the definition of interest rate spreads, the effects of lending and deposit interest rate volatility on 
spreads at any point in time depends on which of the two dominates the other. $\beta_{4}, \beta_{5}, \beta_{7}$, and $\beta_{10}$ are expected to be positive and statistically significant. Broad money growth increases financial sector risk premium which necessitates increases in interest rate spreads. Increasing monetary policy rate increases cost of funds which widens interest rate spreads. Fiscal deficits and public sector borrowing from commercial banks are expected to increase interest rate spreads through their crowding-out effects. $\beta_{6}$, and $\beta_{8}$ are expected to be negative and statistically significant. Quality institutions are associated with good institutional, legal, and regulatory framework which enables them reduce interest rate spreads. Finally, economic growth is expected to reduce interest rate spreads since it provides better technology, increases competition, and provides greater mix of financial opportunities. Annual data for the period 1980-2013 was used. Data on lending interest rate, inflation, exchange rate and deposit interest rate are obtained from the International Monetary Fund (IMF), International Financial Statistics (IFS) data set, 2015. Data on broad money growth and monetary policy rate (i.e. the prime rate) were obtained from the Bank of Ghana. Real GDP per capita and public sector borrowing from commercial banks is sourced from the World Development Indicators (WDI, 2015). Fiscal deficit is sourced from African Development Indicators 2007 CD-ROM (for 1980-2005), World Development Indicators (WDI, 2015), and the Bank of Ghana Statistical Bulletins (various issues, for 2006-2013). Data on Institutional quality is obtained from Polity IV Project, Marshall and Jaggers (2014). A summary of the data type and sources are given in Table 7.

\subsection{Estimation strategy}

The estimations begin with an investigation of the stationarity properties of the variables in equation (1). The parametric Augmented Dickey-Fuller (ADF) method by Dickey and Fuller (1979; 1981) and the non-parametric Phillips-Perron (PP) procedure by Phillips and Perron (1988) are used. Examining stationarity is particularly important in order to avoid spurious regressions. These procedures are also relevant for small sample size time series data such as this. In addition, the PP test serves as a robustness check on the ADF test results as it is able to correct for higher level serial correlation as well as heteroscedasticity that may be present in the ADF results. By the tests, the null hypothesis of unit root, hence, non-stationarity is examined against the alternative hypothesis of no unit root, implying stationarity in each method.

Following the unit root test, cointegration is examined using the Autoregressive Distributed Lag (ARDL) bounds test approach to cointegration (see Pesaran et al., 2001). The procedure is able to accept series that are strictly $I(0)$ or $I(1)$ or a mixture, provided they are not $I(2)$ or more. It is also appropriate for small sample size estimates (34 observations in this case). The conditional Error Correction Model (ECM) used for the ARDL estimation is stated as:

$\Delta Y_{t}=\omega_{0}+\sum_{i=1}^{k} \omega_{1} \Delta Y_{t-i}+\sum_{i=0}^{k} \omega_{m} \Delta X_{t-i}+\gamma_{1} Y_{t-1}+\gamma_{m} X_{t-1}+\varepsilon_{t}$

where $\Delta$ represents the first difference operator, $m$ is the number of regressors, and $\varepsilon_{t}$ represents the error term. $X$ and $Y$ are assumed to be the independent and dependent variables respectively. The ECM is estimated by the OLS method.

The null hypothesis of no cointegration $\left(H_{0}: \gamma_{1}=\gamma_{m}=0\right)$ is examined against the alternative hypothesis of cointegration $\left(H_{0}: \gamma_{1} \neq \gamma_{m} \neq 0\right)$ using the F-test. The bounds test provides the upper and the lower critical values for evaluating the presence or otherwise of cointegration. The 
upper bound critical value assumes all variables to be $I(1)$ while the lower bound critical value assumes them to be $I(0)$. There is cointegration when the estimated F-statistic is greater than the upper bound critical value while no cointegration exists when the estimated F-statistic is less than the lower bound critical value. Inconclusive results for cointegration emerge when the estimated F-statistic lies between the upper and lower bound critical values. Long-and short-run estimates are obtained provided evidence for cointegration emerges. The test is done using EViews 9.

\subsection{Estimation results and discussion 3.1 Unit root and cointegration results}

The unit root test results for the variables in equation (1) are given in Tables 1 and 2. Table 1 contains the ADF unit root test results while Table 2 contains that for PP.

\section{INSERT TABLE 1 HERE}

It is evident from the $\mathrm{ADF}$ and $\mathrm{PP}$ test results that the variables in equation (1) are either integrated of order zero (i.e. $I[0]$ ) or one (i.e. $I[1]$ ), irrespective of whether the test is done with a constant and trend or with a constant but with no trend. Hence, the variables in equation (1) are a mixture of $I(0)$ and $I(1)$ variables. Therefore, the ARDL method for examining cointegration becomes appropriate following the unit root results obtained.

\section{INSERT TABLE 2 HERE}

The results for the ARDL bounds test for cointegration reported in Table 3 indicates cointegration at 1 per cent level. The reason is that, the test statistic of 9.862914 is greater than the upper bound critical value of 3.86 at 1 per cent level of significance. Therefore, there is indeed a valid cointegration relationship between the variables estimated using equation (2). Hence, we move on to provide and discuss the results of the long-and short-run estimates.

\section{INSERT TABLE 3 HERE}

\subsection{Estimated long-run}

The long-run estimates of the macroeconomic determinants of interest rate spreads are given in Table 4. The coefficient of exchange rate volatility is positive and statistically significant at 5 per cent level. Hence, an increase in exchange rate volatility leads to increases in interest rate spreads. This is expected as increasing exchange rate volatility creates greater uncertainty, leading to banks fixing higher risk premiums which eventually increases interest rate spreads by increasing lending rates. Besides, exchange rate volatility is an indicator of macroeconomic instability which increases the levels of risks faced by commercial banks. This causes commercial banks to vary their pricing attitudes which lead to increased interest rate spreads. Similar result is reported by Chirwa and Mlachila (2004) for Malawi and Folawewo and Tennant (2008) for sub-Saharan African countries.

\section{INSERT TABLE 4 HERE}


The coefficient of deposit interest rate volatility is also positive. Deposit interest rate volatility increases uncertainty with respect to expected profit margin. Banks therefore respond by increasing lending rates. This causes interest rate spreads to increase. Similar evidence is provided by Brock and Suarez (2000) for Latin America.

Lending rate volatility also has a negative relationship with interest rate spreads, implying increasing lending interest rate volatility reduces interest rate spreads. The coefficient of the lending rate volatility variable is however statistically insignificant. Brock and Suarez (2000) find similar evidence for Colombia.

As expected, the coefficient of the institutional quality variable, PT is negative and statistically significant at 1 per cent level. The implication is that, good institutional quality reduces interest rate spreads. This is so since regulation and enforcement are easier under such conditions. Moreover, a level playing field is created under such circumstances which encourage competition, causing spreads to reduce. Chirwa and Mlachila (2004), Crowley (2007), and Adu et al. (2013) emphasize the importance of quality institutions in controlling interest rate spreads.

The coefficient of the fiscal deficit variable shows a positive relationship between fiscal deficit and interest rate spreads. The coefficient is statistically significant at 1 per cent level. This may be so because deficits cause greater public involvement on the local financial markets which eventually increases interest rate spreads through increasing lending rate. Continues domestic borrowing to finance fiscal deficits is therefore likely to continually increase interest rate spreads (see ISSER, 2013; Bawumia, 2014). The results confirm that provided by Aisen, and Hauner, (2008) for a panel of 60 advanced and emerging countries and Laubach (2009) for U.S.A.

The coefficient of economic growth, $\mathrm{Y}$, is positive and statistically significant at 1 per cent level. It is the largest long-run driver of interest rate spreads per the estimated results. The positive impact of economic growth on interest rate spreads is explained as follows. Economic growth causes more specialized financial institutions to emerge. As financial institutions become more and more specialized, the financial market deepens. This causes riskier borrowers to emerge as it becomes easier to access funds. Unfortunately, riskier borrowers tend to have better access to funds since such borrowers mostly pay higher interest rates. This increases financial sector risk premiums. Increases in risk premiums are transmitted to higher lending rates, eventually leading to greater interest rate spreads. This may occur if the portion of bank loans devoted to retail as well as specialized lending is relatively large, leading to larger interest rate spreads not dependent on lending rates (Demirguc-Kunt and Huizinga, 1999). Moreover, as stated by Demirguc-Kunt and Huizinga (1999) the level of economic growth in any country is an indicator of the differences in banking technology as well as the mix of banking opportunities that may be available. If the level of banking technology and the mix of available banking opportunities vary greatly among commercial banks, interest rate spreads is likely to increase with economic growth (Demirguc-Kunt and Huizinga, 1999). This may also explain the results obtained here as the situation in Ghana is not different. The reason is that Ghana's financial system is currently diversified in terms of the range of services it provides. In addition, financial institutions are becoming increasingly innovative with new products and technology. Entry has been liberalized which has encouraged foreign financial institutions and investors to enter. This has increased competition among financial institutions, and introduced strong business practices, and risk 
management systems which may be creating higher spreads (Bank of Ghana, 2007; Adu, et al., 2013; Ackah and Asiamah, 2014). Crowley (2007), Ben Naceur and Goaied (2008), and Garr and Kyereboah-Coleman (2013) provide similar results for sub-Saharan African countries, Tunisia and Ghana respectively.

Even though the coefficients of broad money growth, monetary policy rate, and public sector borrowing from commercial banks are positive, they are however not statistically significant. It was expected that money growth, monetary policy rate, and public sector borrowing from commercial banks increase interest rate spreads. This is so since broad money growth creates inflationary pressures which increases risk premium and hence interest rate spreads. Monetary policy rate, on the other hand, increases cost of funds which may be passed on as increased lending rates that eventually increase interest rate spreads. The positive coefficient of the public sector borrowing from commercial banks variable indicates government intervention in the banking sector likely crowds-out credit to the private sector. Competition for credit is stifled and this causes lending rates to soar, which increases interest rate spreads. This is because banks find it more lucrative to lend to government compared to private borrowers, given that government is less likely to default on loans. Folawewo and Tennant (2008) provide similar evidence on broad money growth for Sub-Saharan African countries while Churchill et al. (2014) corroborates the results for the monetary policy rate variable for Ghana. The results for the public sector borrowing from commercial banks variable confirms that of Folawewo and Tennant (2008) for Sub-Saharan African countries but contradicts those of Garr and Kyereboah-Coleman (2013) and Sheriff and Amoako (2014) for Ghana. Finally, the long-run coefficient of inflation is positive but statistically insignificant. Naceur and Goaeid (2008), and Churchill et al., (2014), and Amuakwah-Mensah and Marbuah (2015) find similar evidence for Tunisia and Ghana respectively.

\subsection{Short-run results}

The short-run results are presented in Table 5. The coefficients of inflation, deposit interest rate volatility, fiscal deficit, public sector borrowing from commercial banks, lending rate volatility, exchange rate volatility, broad money growth, institutional quality, as well as economic growth do not differ in sign from those of the long-run. However, only the short-run coefficient of exchange rate volatility, fiscal deficit, public sector borrowing from commercial banks, and lending rate volatility are statistically significant. In the short-run, the monetary policy rate variable is negative and statistically significant at 5 per cent level.

\section{INSERT TABLE 5 HERE}

The paper examines the adequacy and reliability of the ARDL model by considering their statistical properties. The results are given in Table 6. The paper examines serial correlation using Breusch-Godfrey LM test, heteroscedasticity using the Breusch-Pagan-Godfrey, and normality using Jarque-Berra test. The results show the model passes all these diagnostic and reliability tests. Further, model stability tests done using the CUSUM and CUSUMSQ statistic indicates the model is stable over the period considered. The error correction term [ecm(-1)] is negative and statistically significant at 1 per cent level. It shows a very high rate of convergence annually to long-run equilibrium after every short-run shock. Specifically, 89 per cent of short- 
run shocks are corrected annually. The error correction term also confirms the cointegration relationship stated earlier which further shows that the long-and short-run results are not spurious.

\section{INSERT TABLE 6}

\subsection{Concluding remarks}

The paper has investigated macroeconomic determinants of interest rate spreads in Ghana for the period 1980-2013. The autoregressive distributed lag bounds test to cointegration was used for the estimation. Macroeconomic variables considered were exchange rate volatility, lending interest rate volatility, public sector borrowing from commercial banks (crowing-out effect), deposit interest rate volatility, economic growth, fiscal deficit, inflation, monetary policy rate, and a measure of institutional quality. The test for cointegration shows evidence of cointegrating relationship between these variables. The long-run estimates indicate inflation, fiscal deficit, crowding-out effect, exchange rate volatility, deposit interest rate volatility, economic growth, money growth, and monetary policy rate increase interest rate spreads in Ghana. However, only the long-run coefficient of exchange rate volatility, fiscal deficit, public sector borrowing from commercial banks, and economic growth were statistically significant. Institutional quality and lending interest rate volatility were found to reduce interest rate spread in the long-run, but the coefficient of the lending interest rate variable was not statistically significant. From the shortrun results, inflation, exchange rate volatility, deposit interest rate volatility, money growth, fiscal deficit, economic growth, public sector borrowing from commercial banks (i.e. crowdingout effect) increase interest rate spreads, but only the coefficients of exchange rate volatility, fiscal deficit, and public sector borrowing from commercial banks were statistically significant. The short-run coefficients of the institutional quality variable, monetary policy rate, lending rate volatility were negative, but the coefficient of the institutional quality variable was not statistically significant.

From the results, all fiscal policy variables (public sector borrowing from commercial banks, and fiscal deficits) were statistically significant in both the long-and the short-run. On the other hand, for monetary policy variables, only the coefficient of exchange rate volatility was statistically significant in the long-run while only the coefficients of exchange rate volatility, monetary policy rate, and lending interest rate volatility are statistically significant in the short-run. It can therefore be said that the effects of fiscal policy variables on interest rate spreads dominate monetary policy variables. This implies instabilities in fiscal policy variables are likely to create greater risks and uncertainties in the financial sector which may translate into higher interest rate spreads. Notwithstanding, the nation's monetary and fiscal policy authorities must put in place necessary policies to control macroeconomic instability in general since such instabilities are associated with risks and uncertainties which necessitate wider interest rate spreads. Also, the central government must reduce its borrowing from domestic financial institutions since the crowding-out effect associated with such borrowing increases interest rate spreads. The central bank must put in place appropriate measures to control the depreciation of the Ghana Cedi since the volatility of the domestic currency increases interest rate spreads. The central government must control its excessive spending since the fiscal deficits that arise from it increases interest rate spreads. The results of the institutional quality variable imply quality institutions can better reduce interest rate spreads. Given this, the central bank must improve its monitoring and evaluation measures to ensure banks comply with policy-determined interest rates. 


\section{Reference}

Aboagye, AQ., Akoena, SK., Antwi-Asare, TO., and Gockel, AF. (2008), "Explaining interest rate spreads in Ghana”. African Development Review, 20(3), 378-399.

Ackah, C., and Asiamah, JP. (2014), "Financial regulation in Ghana: Balancing inclusive growth with financial stability". Shaping Policy for Development. Working Paper, 410.

Adu, G., Marbuah, G., and Mensah, JT. (2013), "Financial development and economic growth in Ghana: Does the measure of financial development matter?". Review of Development Finance, 3(4), 192-203.

Aisen, A. and Hauner, D. (2008). Budget deficits and interest rates: A fresh perspective (No. 2008-2042). International Monetary Fund.

Amidu, M. (2006), "The link between monetary policy and banks lending behaviour: The Ghanaian case", Banks and Banking system. Vol.1. Issue 4. 2006.

Amuakwa-Mensah, F. and Mabuah, G. (2015), "The determinants of net interest margin in the Ghanaian banking industry", Journal of African Business, 16:3, 272-288.

Aryeetey, E. and Senbet, LW. (2004), Essential financial market reforms in Africa. Technical Publication No. 63, Institute of Statistical, Social and Economic Research, University of Ghana, Legon.

Bain, JS. (1951), "Relation of profit rate to industry concentration: American manufacturing, 1936-1940", The Quarterly Journal of Economics, 293-324.

Bank of Ghana (2007), "Building a financial sector for an emerging market economy. Implications for the capitalization of bank and non-bank financial institutions". Bank of Ghana Consultation Paper.

Bank of Ghana, Bank of Ghana Statistical Bulletins (various issues for 2006-2013).

Barajas, A., Steiner R. and Salazar, N. (1999), "Interest spreads in banking in Colombia, 197496, IMF Staff Papers, 196-224.

Barajas, A., Steiner R. and Salazar, N. (2000), "The impact of liberalization and foreign investment in Colombia's financial sector", Journal of Development Economics, 63(1), 157-196.

Bawumia, M. (2014), Restoring the value of the cedi. Distinguished Speaker Series Lecture. Central University College, Ghana. March 25, 2014.

Bawumia, M., Belnye, F., and Ofori, M. E. (2005), "The determination of bank interest spreads in Ghana: An empirical analysis of panel data". Bank of Ghana, Working Paper SeriesWp/Bog2005/09. 
Ben Naceur, S., and Goaied, M. (2008), "The determinants of commercial bank interest margin and profitability: evidence from Tunisia". Frontiers in Finance and Economics, 5(1), 106-130.

Biekpe, N. (2011), "The competitiveness of commercial banks in Ghana", African Development Review, Vol. 23. No. 75-78

Brock, P. and Franken, H. (2002), Bank interest margins meet interest rate spreads: How good is balance sheet data for analyzing the cost of financial intermediation. Unpublished paper.

Brock, P. and Franken, H. (2003), "Measuring the determinants of average and marginal bank interest rate spreads in Chile, 1994-2001”, Economía Chilena, 6(3), 45-65.

Brock, PL. and Suarez, LR. (2000), "Understanding the behavior of bank spreads in Latin America", Journal of Development Economics, 63(1), 113-134.

Chirwa, EW. and Mlachila, M. (2004), "Financial reforms and interest rate spreads in the commercial banking system in Malawi”, IMF Staff papers, 96-122.

Churchill, RQ, Kwaning, CO., and Ababio, O. (2014), "The determinant of bank interest rates spreads in Ghana", International Journal of Economic Behavior and Organization, 2(4): 49-57.

Crowley, J. (2007), "Interest rate spreads in English-speaking African countries", IMF Working Papers, 1-34.

Demirgüç-Kunt, A. and Huizinga, H. (1999), "Determinants of commercial bank interest margins and profitability: Some international evidence", The World Bank Economic Review, 13(2), 379-408.

Demirgüç-Kunt, A., Huizinga, H. and Claessens, S. (1998), "How does foreign entry affect the domestic banking market?”. World Bank Policy Research Working Paper, (1918).

Dickey, DA. and Fuller, WA. (1979), "Distribution of the estimators for autoregressive time series with a unit root", Journal of the American Statistical Association, 74(366a), 427-431.

Dickey, DA. and Fuller, WA. (1981), "Likelihood ratio statistics for autoregressive time series with a unit root", Econometrica: Journal of the Econometric Society, 1057-1072.

Folawewo, AO., and Tennant, D. (2008, July), "Determinants of interest rate spreads in SubSaharan African countries: A dynamic panel analysis". In A paper prepared for the 13th Annual African Econometrics Society Conference (pp. 9-11).

Garr, DK and Kyereboah-Coleman, A. (2013), "Macroeconomic and industry determinants of interest rates spread-Empirical evidence". Journal of Developing Country Studies, Vol. 3, No. 12.

Gelos, G. (2006), Banking spreads in Latin America. 
Ghana, (2014), Article IV consultation-staff report; press release; and statement by the executive director for Ghana; International Monetary Fund, IMF Country Report No. 14/129.

Hannan, TH. and Berger, AN. (1991), "The rigidity of prices: Evidence from the banking industry", The American Economic Review, 938-945.

Ho, TS. and Saunders, A. (1981), "The determinants of bank interest margins: Theory and empirical evidence", Journal of Financial and Quantitative analysis, 16(04), 581-600.

Hofmann, B. and Mizen, P. (2004), "Interest rate pass-through and monetary transmission: Evidence from individual financial institutions' retail rates", Economica, 71(281), 99-123.

International Monetary Fund (2015), International Financial Statistics, Washington. DC: International Monetary Fund.

ISSER, (2013), Policies and options for Ghana's economic development, Legon: Institute of Statistical, Social and Economic Research, University of Ghana.

Jayaraman, TK. and Sharma, R. (2003), "Why is interest rate spread high in Fiji? Results from a preliminary study".

Korsah, K., Nyarko, EK. and Tagoe, NA. (2001), "Impact of financial sector liberalization on competition and efficiency in the Ghanaian banking industry", International Labor Organization Research paper, 01-2, 1-51.

Kwakye, J. K. (2010). High Interest Rates in Ghana: A Critical Analysis. IEA Ghana.

Laubach, T. (2009). New evidence on the interest rate effects of budget deficits and debt. Journal of the European Economic Association, 7(4), 858-885.

Marshall, MG., Jaggers, K. and Gurr, TR. (2014), Polity IV Annual Time-Series, 1800-2013.

Moore, W. and Craigwell, R. (2002), "Market power and interest rate spreads in the Caribbean", International Review of Applied Economics, 16(4), 391-405.

Neumark, D. and Sharpe, SA. (1992), "Market structure and the nature of price rigidity: Evidence from the market for consumer deposits", The Quarterly Journal of Economics, 657680.

Ngugi, R. (2001), An empirical analysis of interest rate spread in Kenya (Vol. 106). Nairobi: African Economic Research Consortium.

Owusu-Antwi, G. and Antwi, J. (2013), "Do financial sector reforms improve competition of banks? An application of Panzar and Rosse model: The case of Ghanaian banks", International Journal of Financial Research, Vol. 4, No. 3; 2013. 
Peria, MSM. and Mody, A. (2004), "How foreign participation and market concentration impact bank spreads: Evidence from Latin America", Journal of Money, Credit and Banking, 511-537.

Pesaran, MH., Shin, Y. and Smith, RJ. (2001), "Bounds testing approaches to the analysis of level relationships", Journal of Applied Econometrics, 16(3), 289-326.

Phillips, PC. and Perron, P. (1988), "Testing for a unit root in time series regression", Biometrika, 75(2), 335-346.

Quartey, P. and Afful-Mensah, G. (2014), "Financial and monetary policies in Ghana: A review of recent trends", Review of Development Finance, 4 (2), 115-125.

Randall, MR. (1998), Interest rate spreads in the Eastern Caribbean, International Monetary Fund.

Robinson, JW. (2002), Commercial bank interest rate spreads in Jamaica: Measurement and prospects, www.boj.org.jm/uploads/pdf/papers pamphlets.pdf

Sarpong, D., Winful, EC., and Ntiamoah, J. (2011)," Determinants of wide interest margins in Ghana: panel EGLS analysis". Available at SSRN 1908951.

Sheriff, I., and Amoako, G. (2014). "Macroeconomic Determinants of Interest rate Spread in Ghana: Evidence from ARDL Modelling Approach". Journal of Finance and Bank Management, 2(2), 115-132.

Sologoub, D. (2006), The determinants of bank interest margins and profitability: Case of Ukraine, In Workshop on transition economics, Helsinki.

Tennant, D. (2006), "Are interest rate spreads in Jamaica too large? Views from within the financial sector”, Social and Economic Studies, 88-111.

Valderrama, ML. and Samuel, MWA. (2006), The monetary policy regime and banking spreads in Barbados (No. 6-211), International Monetary Fund.

World Bank (2015), World Development Indicators, Washington, DC: World Bank. 
Tables

Table 1: ADF Unit root test results

\begin{tabular}{|c|c|c|c|c|}
\hline 20 & \multicolumn{2}{|c|}{ Levels } & \multicolumn{2}{|c|}{ First Difference } \\
\hline Variables & Constant & $\begin{array}{c}\text { Constant and } \\
\text { Trend }\end{array}$ & Constant & $\begin{array}{c}\text { Constant and } \\
\text { Trend }\end{array}$ \\
\hline$L N I R S$ & -1.392 & $-3.857 * *$ & $-8.973 * * *$ & 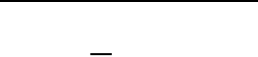 \\
\hline$L N M P$ & -1.780 & -1.920 & $-7.253 * * *$ & $-7.341 * * *$ \\
\hline LNCROWD & -2.541 & -2.605 & $-5.759 * * *$ & $-5.674 * * *$ \\
\hline$L N I N F$ & $-3.489 * *$ & $-5.184 * * *$ & - & - \\
\hline$E E R_{\text {vol }}$ & 3.832 & 3.105 & 3.812 & 0.654 \\
\hline$M 2_{g}$ & $-4.713 * * *$ & $-5.370 * * *$ & & - \\
\hline$D E F$ & 6.742 & 5.487 & 2.231 & 1.128 \\
\hline$P T$ & -1.056 & $-8.874 * * *$ & $-12.130 * * *$ & - \\
\hline$D R_{\text {vol }}$ & -2.912 & -3.026 & $-5.433 * * *$ & $-5.329 * * *$ \\
\hline$L N Y$ & 3.010 & -0.203 & $-4.708 * * *$ & $-5.833 * * *$ \\
\hline$L R_{\text {vol }}$ & $-3.132 * *$ & -3.071 & & $-6.222 * * *$ \\
\hline
\end{tabular}

Source: Authors

Note: ${ }^{* * *}(* *)(*)$ denotes significance at $1 \%, 5 \%$ and $10 \%$ respectively

Table 2: PP unit root test results

\begin{tabular}{|c|c|c|c|c|}
\hline \multirow[b]{2}{*}{ Variables } & \multicolumn{2}{|c|}{ Levels } & \multicolumn{2}{|c|}{ First Difference } \\
\hline & Constant & $\begin{array}{c}\text { Constant and } \\
\text { Trend } \\
\end{array}$ & Constant & $\begin{array}{c}\text { Constant and } \\
\text { Trend } \\
\end{array}$ \\
\hline$L N I R S$ & -2.377 & $-3.877 * *$ & $-9.075 * * *$ & $-8.919 * * *$ \\
\hline$L N M P$ & -1.731 & -1.817 & $-7.158 * * *$ & $-7.367 * * *$ \\
\hline LNCROWD & $-2.621 *$ & -2.728 & $-6.063 * * *$ & $-5.940 * * *$ \\
\hline$L N I N F$ & $-3.387 * *$ & $-5.356 * * *$ & - & - \\
\hline$E E R_{\text {vol }}$ & 1.690 & -1.200 & $-10.205 * * *$ & $-12.935 * * *$ \\
\hline$M 2_{g}$ & $-4.725 * * *$ & $-11.161 * * *$ & - & - \\
\hline$D E F$ & 18.403 & 14.521 & $-7.889 * * *$ & $-9.315 * * *$ \\
\hline$P T$ & -1.170 & $-7.320 * * *$ & $-13.591 * * *$ & $-12.848 * * *$ \\
\hline$D R_{\text {vol }}$ & -2.170 & -2.214 & $-5.767 * * *$ & $-5.449 * * *$ \\
\hline$L N Y$ & 3.010 & -2.422 & $-2.711 * *$ & $-3.398 * *$ \\
\hline$L R_{\text {vol }}$ & $-3.136 * *$ & -3.075 & & $-8.067 * * *$ \\
\hline
\end{tabular}

Source: Authors

Note: $* * *(* *)(*)$ denotes significance at $1 \%, 5 \%$ and $10 \%$ respectively 
Table 3: ARDL bounds test for Cointegration

Test Statistic 9.862914***

Source: Authors

Note: $* * *$ implies that the null hypothesis of no cointegration is rejected at 1 per cent level of statistical significance. The ARDL model gives the 99 per cent lower and upper bounds as 2.54 and 3.86 respectively.

Table 4: Estimated long-run results using ARDL approach

\begin{tabular}{ccc}
\hline Variable & Coefficient & Standard Error \\
\hline $\ln I N F$ & 0.100 & 0.098 \\
$E E R_{\text {vol }}$ & $2.161^{* *}$ & 1.002 \\
$D R_{\text {vol }}$ & 0.004 & 0.002 \\
$M 2_{g}$ & 0.008 & 0.008 \\
$\ln M P$ & 0.262 & 0.152 \\
$P T$ & $-0.362^{* * *}$ & 0.085 \\
$D E F$ & $0.000135^{* * *}$ & 0.020 \\
$\ln Y$ & $11.433^{* * *}$ & 2.066 \\
$\ln C R O W D$ & $0.993^{* *}$ & 0.345 \\
$L R_{\text {vol }}$ & -0.000751 & 0.001 \\
$C$ & $-73.231^{* * *}$ & 13.892 \\
\hline
\end{tabular}

Source: Authors

Notes: $\ln I R S$ is the dependent variable. $* * *(* *)(*)$ indicate rejection of the null hypothesis at $1(5)(10)$ per cent level of statistical significance respectively.

Table 5: Estimated short-run results using ARDL approach

\begin{tabular}{ccc}
\hline Variable & Coefficient & Standard Error \\
\hline$\Delta \ln I N F$ & 0.089 & 0.165 \\
$\Delta E E R_{\text {vol }}$ & $1.376^{* * *}$ & 0.484 \\
$\Delta D R_{\text {vol }}$ & 0.002 & 0.001 \\
$\Delta M 2_{g}$ & 0.001 & 0.005 \\
$\Delta P T$ & -0.054 & 0.061 \\
$\Delta \ln M P$ & $-0.862^{* *}$ & 0.430 \\
$\Delta D E F$ & $0.000021^{* * *}$ & 0.003 \\
$\Delta \ln Y$ & 4.084 & 3.119 \\
$\Delta \ln C R O W D$ & $0.452^{* *}$ & 0.197 \\
$\Delta L R_{\text {vol }}$ & $-0.002^{* *}$ & 0.001 \\
$e c m(-1)$ & $-0.890^{* * *}$ & 0.203
\end{tabular}

Source: Authors

Notes: $\ln I R S$ is the dependent variable. ${ }^{* *}\left({ }^{* *}\right)$ indicate rejection of the null hypothesis at 1 per cent $(5$ per cent) level of statistical significance respectively. 
Table 6: Model reliability and stability tests

\begin{tabular}{cc}
\hline Test statistic & Results \\
\hline Serial correlation & 0.453013 \\
& $(0.5162)$ \\
Normality & 0.857118 \\
& $(0.651447)$ \\
Heteroscedasticity & 1.586351 \\
& $(0.2173)$ \\
CUSUM & Stable \\
CUSUMSQ & Stable \\
\hline
\end{tabular}

Source: Authors

Note: In parentheses are probability values

Figure 2: CUSUM and CUSUMSQ diagrams for the general model

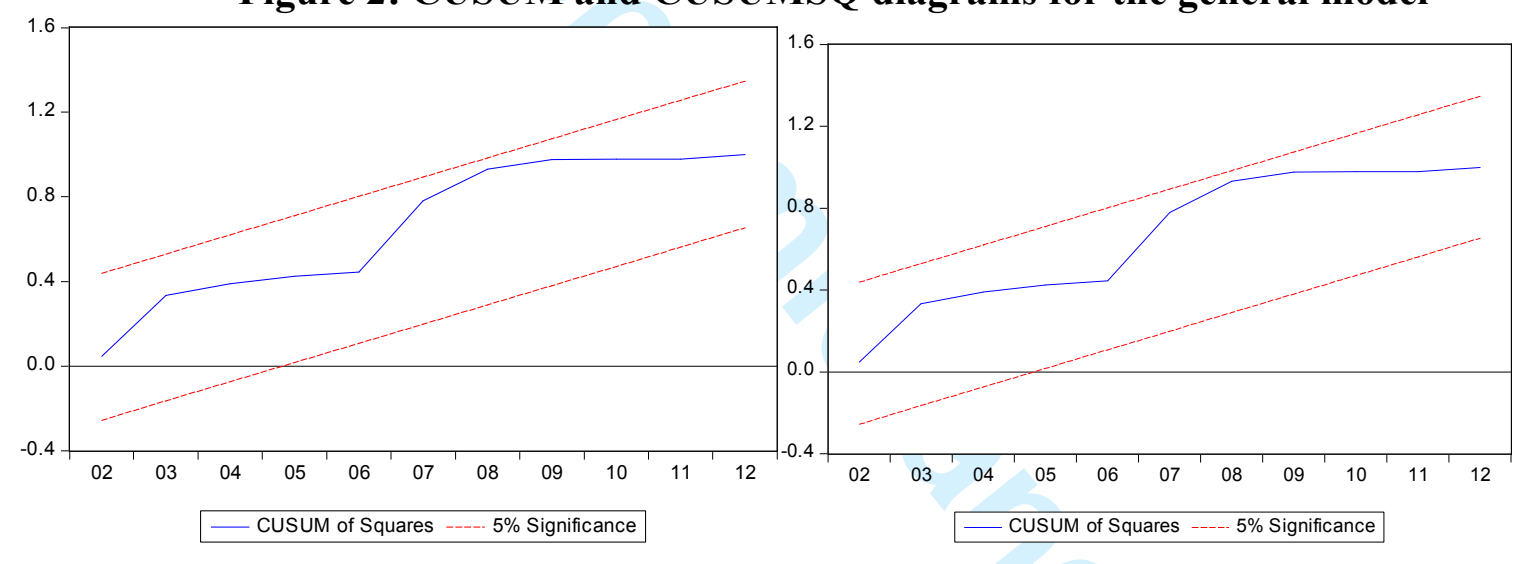

37

38

39

40

41

42

43

44

45

46

47

48

49

50

51

52

53

54

55

56

57

58

59

60 
Table 7: Summary of data type and sources

\begin{tabular}{|c|c|c|c|}
\hline Variable name & Measure & Expected sign & Source \\
\hline Interest rate spread & $\begin{array}{l}\text { Lending interest rate } \\
\text { minus Deposit interest rate }\end{array}$ & & $\begin{array}{c}\text { International Monetary } \\
\text { Fund (IMF), International } \\
\text { Financial Statistics (IFS) } \\
\text { data set, 2015 }\end{array}$ \\
\hline Inflation & Consumer price index & + & $\begin{array}{c}\text { International Monetary } \\
\text { Fund (IMF), International } \\
\text { Financial Statistics (IFS) } \\
\text { data set, } 2015\end{array}$ \\
\hline Exchange rate volatility & $\begin{array}{l}\text { Derived from nominal } \\
\text { exchange rate using the } \\
\text { GARCH }(1,1) \text { approach }\end{array}$ & + & $\begin{array}{c}\text { International Monetary } \\
\text { Fund (IMF), International } \\
\text { Financial Statistics (IFS) } \\
\text { data set, } 2015\end{array}$ \\
\hline Deposit interest rate & $\begin{array}{l}\text { Derived from deposit } \\
\text { interest rate using the } \\
\text { GARCH }(1,1) \text { approach }\end{array}$ & $+/-$ & $\begin{array}{c}\text { International Monetary } \\
\text { Fund (IMF), International } \\
\text { Financial Statistics (IFS) } \\
\text { data set, 2015 }\end{array}$ \\
\hline Broad money growth & $\begin{array}{l}\text { Average annual growth } \\
\text { rate in money and quasi } \\
\text { money }\end{array}$ & + & Bank of Ghana \\
\hline Monetary policy rate & Prime rate & + & Bank of Ghana \\
\hline Institutional quality & Polity2 & - & $\begin{array}{c}\text {.Polity IV Project } \\
\text { (Marshall and Jaggers, } \\
\text { 2014) }\end{array}$ \\
\hline Fiscal deficit & $\begin{array}{l}\text { Overall balance including } \\
\text { grants and net lending but } \\
\text { excluding divestiture } \\
\text { receipts and liabilities } \\
\text { expressed as a percentage } \\
\text { of nominal GDP }\end{array}$ & + & $\begin{array}{c}\text { African Development } \\
\text { Indicators 2007 CD-ROM } \\
\text { (for 1980-2005), World } \\
\text { Bank, and the Bank of } \\
\text { Ghana Statistical Bulletins } \\
\text { (various issues, for 2006- } \\
\text { 2013) }\end{array}$ \\
\hline Economic growth & Real GDP per capita & - & $\begin{array}{c}\text { World Bank, World } \\
\text { Development Indicators } \\
\text { (WDI, 2015) }\end{array}$ \\
\hline $\begin{array}{l}\text { Public sector borrowing } \\
\text { from commercial banks }\end{array}$ & $\begin{array}{l}\text { Domestic credit provided } \\
\text { by the financial sector } \\
\text { minus Domestic credit to } \\
\text { private sector by banks }\end{array}$ & + & $\begin{array}{c}\text { World Bank, World } \\
\text { Development Indicators } \\
\text { (WDI, 2015) }\end{array}$ \\
\hline Lending rate volatility & $\begin{array}{l}\text { Derived from lending } \\
\text { interest rate using the } \\
\text { GARCH }(1,1) \text { approach }\end{array}$ & $+/-$ & $\begin{array}{c}\text { International Monetary } \\
\text { Fund (IMF), International } \\
\text { Financial Statistics (IFS) } \\
\text { data set, } 2015\end{array}$ \\
\hline
\end{tabular}

Source: Authors 